\title{
OCENA WLASNEGO CIAŁA ORAZ STANU ZDROWIA U OSÓB TRANSSEKSUALNYCH
}

\begin{abstract}
Abstrakt. Transseksualizm definiowany jest jako zakłócenie identyfikacji płciowej, które polega na rozbieżności między psychicznym poczuciem przynależności do danej płci a biologiczną budową ciała, płcią metrykalną, socjalną oraz prawną. Ponieważ nie istnieje metoda, która pozwoliłaby na dopasowanie identyfikacji płciowej do ciała człowieka, oddziaływanie leczniczo-terapeutyczne koncentruje się na odwrotnym zabiegu: dostosowuje cielesność do wykazywanej tożsamości płciowej. Wskazuje się, że osoby transseksualne są więźniami własnych ciał - transseksualni mężczyźni cierpią w ciele kobiecym, transseksualne kobiety - w ciele męskim, co niejednokrotnie wiąże się z odrzuceniem swojego ciała, niechęcią do niego, awersją do zewnętrznych narządów płciowych. Proces korekty płci przebiega wielopłaszczyznowo, obejmując wieloaspektową diagnostykę, prawną zmianę danych osobowych, kurację hormonalną oraz zabiegi operacyjne. Osoby transseksualne są narażone na wiele skutków ubocznych kuracji hormonalnych oraz komplikacji pooperacyjnych. Wskazuje się również, że medyczny proces korekty płci skraca czas przeżycia od kilkunastu do kilkudziesięciu lat. W niniejszym artykule zostanie przedstawiona tematyka cielesności oraz stanu zdrowia osób transseksualnych. Autor dokona analizy odpowiedzi dotyczących oceny własnego ciała oraz stanu zdrowia udzielonych przez 16 osób transseksualnych, które wzięły udział w badaniu. Analizy są początkiem szerzej zakrojonych badań nad różnorodnymi aspektami zaburzeń tożsamości płciowej.
\end{abstract}

Słowa kluczowe: identyfikacja płciowa, transseksualizm, korekta płci, cielesność, zdrowie.

\section{Tożsamość płciowa i role płciowe}

Tożsamość płciowa przez niektórych autorów uważana jest za najważniejszy aspekt tożsamości człowieka (R a w a - K o c h a n ow s k a 2011). Najprościej można ją zdefiniować jako bycie kobietą lub mężczyzną. Warto podkreślić, że raz wykształcona tożsamość płciowa jest nieodwracalna, pozostaje w swej istocie niezmienna do końca życia. Poczucie tożsamości płciowej (inaczej: świadomość

* Mgr, Zakład Psychologii Wychowawczej i Psychologii Rodziny, Instytut Psychologii, Wydział Pedagogiki i Psychologii, Uniwersytet Marii Curie-Skłodowskiej, Plac Litewski 5, 20-080 Lublin; e-mail: jonasz.wethacz@umcs.pl. 
tożsamości płciowej) jest jednym z najbardziej zasadniczych czynników determinujących psychiczne funkcjonowanie człowieka.

Zgodnie z podejściem wieloczynnikowym, identyfikacja z płcią umożliwia jednostce określenie siebie w obszarze własnych cech osobowości, postaw i przekonań w kategoriach płciowych (M a nd a 1 2003). Tożsamością płciową nazywa się sposób przeżywania, wewnętrznego odczuwania i doświadczania swojej płci. Mieszczą się w niej wszystkie konfiguracje zachowania człowieka w kategoriach męskości bądź kobiecości. Określa się to mianem tzw. płciowej karty identyfikacyjnej (Now o si elski 2010).

Sandra Bem wyróżnia cztery główne typy poczucia tożsamości płciowej (Rawa-Kochanowska 2011):

- osoby określone płciowo, które cechują się zgodnością między cechami psychicznymi a płcią biologiczną; taka konfiguracja dotyczy kobiecych kobiet i męskich mężczyzn;

- osoby krzyżowo określone płciowo, charakteryzujące się posiadaniem cech psychicznych typowych dla płci przeciwnej biologicznie; wyróżnia się tutaj męskie kobiety i kobiecych mężczyzn;

- osoby androgyniczne, które cechują się wysokim poziomem cech kobiecych i męskich bez względu na swoją płeć biologiczną;

- osoby niezróżnicowane, charakteryzujące się niskim poziomem cech typowych dla którejkolwiek z płci, niezależnie od własnej płci biologicznej.

Przez długie lata sądzono, że dzieci rodzą się bez określonej płci i że jest im ona następnie wpajana w procesie socjalizacji. Badania wykazują jednak, że płeć kształtuje się już w okresie życia płodowego ( $\mathrm{K} \mathrm{u} \mathrm{la,} \mathrm{S} \mathrm{ł} \mathrm{o} \mathrm{w} \mathrm{i} \mathrm{k} \mathrm{o} \mathrm{w} \mathrm{s} \mathrm{k} \mathrm{a} \mathrm{-} \mathrm{H} \mathrm{i} \mathrm{l} \mathrm{c} \mathrm{z} \mathrm{e} \mathrm{r}$ 2003). Również tożsamość płciowa, mająca podłoże neurobiologiczne, określana jest już przed narodzeniem człowieka. Natomiast jej poczucie, świadomość tożsamości płciowej, jest stopniowo nabywane w toku rozwoju ontogenetycznego jednostki w dynamicznym procesie $\mathrm{i}$ jest wynikiem interakcji czynników biologicznych, psychologicznych, społecznych i kulturowych (Rawa-Kochanowska 2011).

Uzewnętrznioną manifestacją tożsamości płciowej jest rola płciowa - mieszczą się w niej wszystkie zachowania, które jednostka przejawia na każdym etapie swojego rozwoju we wszystkich sferach funkcjonowania, będące wyrazem prezentowanej przez nią płci (S e li g m a n i in. 2003). Inaczej określić ją można jako prezentowanie zachowań, akceptowanych w danym społeczeństwie jako typowe dla określonej płci, mające na celu zaznaczenie swojej kobiecości bądź męskości. Jest wyznaczana kulturowo i ma charakter normatywny. Zawiera w sobie oczekiwania społeczne co do tego, w jaki sposób powinni się zachowywać mężczyźni i kobiety (Now o si elsk i 2010). Pozostaje pod znaczącym wpływem stereotypów płciowych, panujących w danym kręgu społeczno-kulturowym. Duży wpływ na ekspresję tożsamości płciowej mają modyfikatory, będące składowymi otoczenia społecznego człowieka. Należą do nich: edukacja społeczna, kształtowanie ról, 
wychowanie, kultura, osobiste doświadczenia oraz naciski religijne i społeczne (Now osielski 2010). W procesie socjalizacji dziecka bardzo dużą rolę odgrywają jego rodzice. Są oni jednocześnie „prototypowymi przedstawicielami dwóch płci" (R a w a - K o c h a no w s ka 2011: 51). Od nich dziecko uczy się, co to znaczy być kobietą i mężczyzną. Wykształcenie prawidłowych ról płciowych może zostać zakłócone, jeśli prezentowana przez rodzica rola płciowa nie jest zgodna ze wzorcami zachowań (w tym: stereotypami płciowymi), panującymi w społeczeństwie. Ponadto zależne jest od oceny (negatywnej bądź pozytywnej), jaką dziecko przypisuje własnej płci (I m i e lińs k i, D u l k o 2001). Także oczekiwania rodziców wobec dziecka warunkują jakość realizowania ról płciowych. Mają one swoje odzwierciedlenie w traktowaniu dzieci (np. zachęcaniu chłopców do większej aktywności fizycznej), doborze kolorów (różowy dla dziewczynek, niebieski dla chłopców), ubiorze czy zakupie zabawek. Również gratyfikacje zachowań typowych dla danej płci będą skutkowały podejmowaniem ich przez dziecko, natomiast wzmocnienia negatywne - unikaniem. Rodzice nie są jedynymi modelami dla dziecka - niebagatelną rolę gra rodzeństwo, dalsi krewni oraz przyjaciele rodziny (P a k ow s ka 2005).

\section{Transseksualizm}

Termin transseksualizm pochodzi z języka łacińskiego: transire oznacza przechodzenie. Transseksualizm określany jest jako „zaburzenie identyfikacji płciowej i roli płciowej, które przejawia się w niezgodności między psychicznym poczuciem płci a biologiczną budową ciała, płcią socjalną, metrykalną oraz prawną" (I mieliński, Dulko 1988: 118).

W Klasyfikacji zaburzeń psychicznych i zaburzeń zachowania ICD-10 transseksualizm zaliczony jest do kategorii Zaburzenia osobowości i zachowania dorostych jako jedno z zaburzeń identyfikacji płciowej (F 64.0). Definiuje się go jako „,pragnienie życia i uzyskania akceptacji jako osoba płci przeciwnej w porównaniu z własną, czemu towarzyszy zazwyczaj uczucie niezadowolenia z własnych, anatomicznych cech płciowych oraz poczucie ich nieprawidłowości, a także chęć poddania się leczeniu hormonalnemu lub operacyjnemu, by upodobnić własne ciało tak dalece, jak tylko to jest możliwe - do ciała płci preferowanej" (ICD-10 2000). Zgodnie ze wskazówkami diagnostycznymi, tożsamość transseksualna powinna utrzymywać się od co najmniej dwóch lat, nie może być wynikiem zaburzeń psychicznych (takich jak schizofrenia) ani nieprawidłowości genetycznych, chromosomowych ani interseksualnych. W ICD-10 wśród zaburzeń identyfikacji płciowej wyróżnia się także transwestytyzm o typie podwójnej roli (F 64.1), zaburzenia identyfikacji płciowej w dzieciństwie (F 64.2), inne zaburzenia identyfikacji płciowej (F 64.8) oraz zaburzenia identyfikacji płciowej nieokreślone (F 64.9). 
W Podręczniku Statystyczno-Diagnostycznym Zaburzeń Psychicznych DSM-V opublikowanym 18 maja 2013 r. przez Amerykańskie Towarzystwo Psychiatryczne transseksualizm już nie występuje. Wprowadzono termin dysforia płciowa, który zdefiniować można jako ekstremalną formę dyskomfortu, związaną z brakiem akceptacji swojej przynależności do określonej płci.

Wyróżnia się dwa typy transseksualizmu, wyodrębnione na użytek kliniczny:

- transseksualizm typu K/M - obejmuje osoby o psychicznym poczuciu przynależności do płci męskiej, mające biologicznie żeńską budowę ciała;

- transseksualizm typu $\mathrm{M} / \mathrm{K}$ - obejmuje osoby o psychicznym poczuciu przynależności do płci żeńskiej, mające biologicznie męską budowę ciała.

$\mathrm{W}$ niniejszym artykule osoby transseksualne $\mathrm{K} / \mathrm{M}$ określane są terminem „transseksualni mężczyźni”, zaś osoby transseksualne M/K - ,transseksualne kobiety", zgodnie z ich identyfikacją z płcią.

Transseksualizm zalicza się do szerszego w swym znaczeniu zespołu dezaprobaty płci. Cechuje się on odczuwaniem przez jednostkę dyskomfortu, wynikającego z niezgodności między psychicznym poczuciem przynależności do danej płci a płcią biologiczną (Imieliński, Dulko 2001). Składają się na niego co najmniej cztery nieakceptowane przez jednostkę obszary: 1) tożsamość płciowa; 2) cielesność; 3) seksualność i 4) rola społeczna (D zie mi an 2008). Do Zespołu Dezaprobaty Płci włącza się również niektóre przypadki transwestytyzmu, homoseksualizmu, psychozy z zaburzeniami identyfikacji płciowej czy też neurozy współwystępującej z agresywnym nastawieniem do swoich genitaliów. Osoby dotknięte Zespołem Dezaprobaty Płci w wielu wypadkach odczuwają subiektywne cierpienie, prowadzące do dysfunkcyjnych technik zaradczych, takich jak autoagresja, próby samobójcze, nałogi i in. (I m i e li ń s ki, D u l k o 2001).

Badania naukowe wskazują na neurobiologiczną etiologię transseksualizmu. Im i e liński i D ulko (2001) wskazują przede wszystkim podłoże hormonalne ukształtowania się transseksualizmu. Nadmierna maskulinizacja mózgu w okresie krytycznym życia płodowego organizmu genotypowo żeńskiego (XX) skutkować będzie wykształceniem się psychicznego poczucia przynależności do płci męskiej (transseksualizm typu $\mathrm{K} / \mathrm{M}$ ), natomiast niedostateczna maskulinizacja organizmu genotypowo męskiego (XY) spowoduje wykształcenie się kobiecej tożsamości płciowej. Etiologię hormonalną wskazuje się jako najbardziej decydującą. Ponadto badania K uli i współpracowników (2012) wykazały, że podwzgórze osób z zaburzoną identyfikacją płciową, tj. transseksualnych typu K/M, wydziela hormony w sposób typowy dla płci męskiej, zaś w przypadku osób transseksualnych typu $\mathrm{M} / \mathrm{K}$ - w sposób typowy dla płci żeńskiej.

Kolejną przyczyną są właściwości strukturalne mózgu. Są to przede wszystkim: jądro łożyskowe prążka krańcowego podwzgórza oraz dymorficzne płciowo jądro okolicy przedwzrokowej. Struktury te rozwijają się pod wpływem określonego stężenia testosteronu między 2 a 5 miesiącem życia płodowego. Badania wykazały, że jądro łożyskowe prążka krańcowego podwzgórza (bed nucleus 
of the stria terminalis, BSTc) u osób transseksualnych typu M/K ma wielkość typową dla genetycznych kobiet (C z a rn e ck a 2003).

Na uwagę zasługuje fakt, że na poczucie tożsamości płciowej może mieć również wpływ sposób odczuwania własnego ciała, warunkowany jakością funkcjonowania pierwszorzędowej kory somatosensorycznej, znajdującej się w płatach ciemieniowych, gdzie przetwarzane są impulsy pochodzące $\mathrm{z}$ różnych rejonów ciała - również z narządów płciowych. Może mieć to związek z akceptacją własnej cielesności w aspekcie płciowości. Neurobiologiczne zaburzenia na tym poziomie mogą mieć związek z brakiem akceptacji własnych ciał (szczególnie narządów rozrodczych) w przypadku osób transseksualnych (www.granicenauki.pl).

Poszukuje się również podłoża genetycznego transseksualizmu. Badania odontometryczne zębów A n t o s z e w s k i e g o (2008) wykazały, że osoby transseksualne typu K/M mają cechy męskie zębów, w sposób znaczący odróżniając się od zębów żeńskich.

Ponadto prawie $1 / 3$ osób transseksualnych cechuje się zaburzonym zapisem EEG (płaty skroniowe - połowa nieprawidłowych fal). Potencjały wywołane z pnia mózgu zgodne z płcią biologiczną (S tr zele cka, Ko ze ra 2007).

Wskazuje się również, że poziom testosteronu w okresie życia płodowego w sposób zasadniczy oddziałuje na rozwijający się mózg dziecka, m.in. zwiększając dominację prawopółkulową i tym samym nie-praworęczność. Z badań Green i Young (2001) wynika, że przypadki nie-praworęczności w populacji osób transseksualnych są znacznie częstsze niż w populacji ogólnej, co wskazuje na nietypową organizację centralnego układu nerwowego zarówno u osób homo-, jak i transseksualnych.

Zdaniem autora artykułu, czynniki środowiskowe nie mają wpływu na pojawienie się transseksualizmu. Oddziaływania zewnętrzne mogą mieć wpływ na nabywanie ról płciowych, ale nie na tożsamość płciową. Brak również empirycznego potwierdzenia wpływów środowiskowych na powstawanie zaburzeń tożsamości płciowej. Co więcej, badania transseksualnych ojców (osoby typu K/M po korekcie płci), którzy dokonali adopcji, wykazały jednoznacznie, że u żadnego z dzieci nie zaobserwowano żadnych odchyleń w zakresie identyfikacji z płcią, mimo że były one świadome transseksualności swojego rodzica (C hil a nd i in. 2013).

\section{Proces korekty płci}

Aktualnie zwraca się uwagę na fakt, że powszechnie używany termin ,zmiana płci" jest nieadekwatny - płeć osób transseksualnych nie jest zmieniana. Jest ona już wykształcona, natomiast korekta chirurgiczna i prawna dokonuje się w celu dopasowania zewnętrznych atrybutów do poczucia tożsamości płciowej. Poprawnym określeniem jest więc „korekta płci” i takie w niniejszym artykule jest używane. 


\section{Medyczna korekta płci osób transseksualnych typu K/M}

\subsection{Kuracja hormonalna}

Kuracja hormonalna trwa do końca życia osoby transseksualnej. W Polsce w przypadku transseksualizmu typu K/M stosowany jest najczęściej Omnadren 250 lub Testosteronum prolongatum. Omnadren 250 jest mieszaniną czterech estrów testosteronu: propionianu, fenylopropionianu, izokapronianu oraz dekanionu. Omnadren 250 jest hormonem androgennym, wykazuje działanie anaboliczne. Inicjuje powstawanie drugo- i trzeciorzędowych cech płciowych, rozrost mięśni szkieletowych, zwiększa gęstość mineralną kości, wzmaga wytwarzanie erytropoetyny w nerkach, zwiększa stężenie hemoglobiny. Wpływa na stymulację i utrzymanie funkcji seksualnych. W przypadku biologicznych kobiet działa także antagonistycznie w stosunku do estrogenów, m.in. hamuje wydzielanie gonadotropin przez przysadkę, hamuje laktację, dochodzi do zaniku menstruacji. Powoduje maskulinizację organizmu: hirsutyzm, łysienie typu męskiego, mutację głosu, zmianę dystrybucji tkanki tłuszczowej, łagodną atrofię gruczołów piersiowych oraz powiększenie łechtaczki.

Skutki uboczne: bezpłodność, łysienie typu męskiego, trądzik, otyłość, retencja wody, sodu, chloru, potasu, wapnia i nieorganicznych fosforanów, obrzmienie ciała spowodowane zatrzymywaniem wody i soli w organizmie, zwiększenie stężenia cholesterolu, hamowanie czynników krzepnięcia II, V, VI i X, policytemia, bóle głowy, parestezje, zmiany libido, zaburzenia funkcji wątroby, plamica wątrobowa, nowotwór wątroby, żółtaczka zastoinowa. Wzrasta poziom pobudzenia i agresji, zmiany nastroju.

\subsection{Zabiegi operacyjne}

Mastektomia jest pierwszym zabiegiem chirurgicznym w procesie korekty płci z żeńskiej na męską. Obejmuje on obustronne usunięcie tkanki piersiowej, powstałego nadmiaru skóry oraz zmniejszenie rozmiaru i umieszczenie we właściwej pozycji brodawki i otoczki sutkowej. Na ogół zabieg ten powoduje całkowitą bądź znaczną utratę czucia w brodawkach sutkowych oraz w obszarach klatki piersiowej objętych operacją, a także powstanie często rozległych blizn pooperacyjnych.

Histerektomia polega na chirurgicznym usunięciu macicy. Wyróżnia się histerektomię całkowitą (usunięcie trzonu i szyjki macicy) oraz częściową (usunięcie trzonu macicy) (M a tu s i a k-K i ta, Z d r o j e w i c z 2009). Histerektomia wykonywana jest trzema metodami: brzuszną (przez powłoki brzuszne), waginalną (przez pochwę) oraz laparoskopową (przez małe nacięcia na powłokach brzusznych) (Malinowski, Maciołek-Blewniewska 2007). U osób 
transseksualnych typu K/M najczęściej wykonuje się histerektomię całkowitą wraz z usunięciem jajników i jajowodów. Zaleca się wykonanie tego zabiegu do 5 lat po rozpoczęciu kuracji hormonalnej. Jest to wskazane z następujących powodów: zwiększone ryzyko nowotworu macicy, szyjki macicy oraz jajników u osób stosujących hormonalną kurację androgenową, zmniejszenie intensywności konfliktu hormonalnego między wewnętrznie produkowanymi estrogenami a zewnętrznie przyjmowanymi androgenami, możliwość zmniejszenia dawek testosteronu oraz zmniejszenie jego skutków ubocznych, zlikwidowanie epizodycznych krwawień/plamień, brak konieczności monitorowania stanu wewnętrznych narządów płciowych, zmniejszenie poczucia kobiecości, zniesienie ryzyka zajścia w ciążę (http://www.gires.org.uk). Histerektomia nieodwracalnie prowadzi do bezpłodności.

Phalloplastyka polega na chirurgicznym wytworzeniu imitacji męskiego członka. Jedną z najbardziej popularnych metod jest metoda mikrochirurgiczna. Członek zostaje wykonany $\mathrm{z}$ własnych tkanek pobieranych z różnych miejsc ciała: przedramienia, pleców, podbrzusza, uda, pośladków. Pobiera się z nich duży płat skóry, naczynia krwionośne (jedną tętnicę oraz dwie lub trzy żyły), fragment tkanki mięśniowej oraz drogi nerwowe, które przyłącza się do unerwienia w obręczy miednicowej. Możliwy jest zabieg z przedłużeniem cewki moczowej (możliwość oddawania moczu przez wytworzonego członka) lub bez niej. Możliwe jest również wykonanie operacji z wykorzystaniem protezy erekcyjnej. Alternatywną formą jest metoidioplastyka. Polega na wytworzeniu członka z łechtaczki. Łechtaczka pod wpływem androgenowej kuracji hormonalnej w wielu przypadkach znacznie się powiększa (w stanie erekcji osiąga rozmiar średnio $4 \mathrm{~cm}$ ). Możliwe jest umieszczenie cewki moczowej wewnątrz wytworzonego członka. Metoda ta jako jedyna zapewnia zachowanie czucia seksualnego. Jej zaletą jest także naturalny wygląd członka. Ograniczeniem jest mały rozmiar, który uniemożliwia penetrację.

\section{Medyczna korekta płci osób transseksualnych typu M/K}

\subsection{Kuracja hormonalna}

Osoby transseksualne typu M/K - podobnie jak transseksualni mężczyźni do końca życia stosują kurację hormonalną. Przebiega ona w postaci przyjmowania hormonów antyandrogenowych: estrogenów i progesteronu. Występują one w różnej formie: plastry, tabletki, drażetki, niekiedy zastrzyki. W Polsce stosuje się m.in. Androcur, Flutamid, Diane i Estraderm. Zażywanie leków antyandrogenowych powoduje powiększenie gruczołów piersiowych, zmianę dystrybucji tkanki tłuszczowej, wygładzenie skóry, zmniejszenie owłosienia ciała, zahamowanie wypadania włosów, a także zmniejszenie rozmiaru jąder, zmniejszenie 
częstości erekcji oraz zmianę barwy głosu. W przypadku osób transseksualnych typu M/K im wcześniej zacznie się kurację hormonalną, tym większe są szanse na sfeminizowania wyglądu zewnętrznego. W późniejszych okresach życia działanie testosteronu jest tak ugruntowane, że sama estrogenowa kuracja hormonalna może być niewystarczająca do osiągnięcia kobiecego wyglądu fizycznego. Stosowanie estrogenowej kuracji hormonalnej powoduje również wiele skutków ubocznych. Mogą być to na przykład: bezpłodność, otyłość, cukrzyca, nadciśnienie tętnicze, zakrzepica, kamień żółciowy, choroby wątroby, nowotwór sutka, a także senność i labilność emocjonalna (http://www.healthnet.com).

\subsection{Zabiegi operacyjne}

Zabiegi operacyjne przeprowadzane u osób transseksualnych w trakcie procesu korekty płci określa się jako SRS (Sex Reassignment Surgery). W przypadku osób transseksualnych typu M/K polegają one na chirurgicznym przekształceniu genitaliów męskich w narządy płciowe żeńskie. Główne cele to: utworzenie wrażliwego czuciowo sromu, skrócenie cewki moczowej oraz utworzenie otworu umożliwiającego oddawanie moczu, utworzenie wrażliwej czuciowo pochwy o rozmiarze umożliwiającym penetrację, zachowanie możliwości osiągania orgazmu. W skład postępowania operacyjnego wchodzą:

- penektomia - amputacja prącia;

- waginoplastyka - utworzenie pochwy; w tym celu pobiera się skórę z amputowanego prącia i moszny, którą wykorzystuje się do wyścielenia pochwy;

- orchidektomia - obustronne usunięcie jąder;

- labioplastyka - utworzenie warg sromowych; wargi sromowe mniejsze tworzone są ze skóry napletka bądź prącia, wargi sromowe większe - ze skóry moszny;

- clitoroplastyka - utworzenie łechtaczki z fragmentu żołędzi (http://transhealth.vch.ca).

Przeprowadza się również zabiegi chirurgiczne mające na celu feminizację twarzy (FFS - Face Feminization Surgery). Twarze zawierają wiele elementów wyraźnie zróżnicowanych płciowo: u mężczyzn są one na ogół większe, cechują się bardziej kanciastym konturem, szeroką żuchwą, mniej wyraźnymi kościami policzkowymi, bardziej wydatnymi łukami brwiowymi, niżej osadzonymi brwiami, wyższą linią włosów, szerszym nosem, cieńszymi wargami i szerszymi ustami oraz większą odległością nosa od ust (http://www.staff.amu.edu.pl). Wiele transseksualnych kobiet poddaje się tego typu operacjom, aby w jak największym stopniu sfeminizować swój wygląd zewnętrzny. Kobiety, które przeszły tego typu operacje, cechują się istotnie wyższym stopniem jakości życia. Ponadto często zmiany są niezbędne do ich prawidłowego funkcjonowania społecznego, ponieważ ich wygląd nie budzi wątpliwości co do reprezentowanej przez nie płci. W skład FFS wchodzą m.in.: piłowanie kości czoła i wałów nadoczodołowych, brody oraz 
szczęki, zmniejszenie jabłka Adama, obniżenie linii włosów, podniesienie brwi, podniesienie czoła, naciągnięcie skóry szyi, podniesienie i powiększenie ust, plastyka nosa, wstawienie implantów w policzki, laserowa depilacja twarzy. FFS ma swoje ograniczenia: nie zawsze efekt końcowy jest w pełni satysfakcjonujący, np. nie ma możliwości zwężenia bardzo szerokiej, kanciastej szczęki do rozmiaru typowo kobiecego. Ponadto przeprowadzane są za granicą, co wiąże się z dużymi nakładami finansowymi: od kilkunastu do nawet kilkuset tysięcy złotych. Ponadto często osoby transseksualne typu $\mathrm{M} / \mathrm{K}$ decydują się również na chirurgiczne powiększanie piersi (http://www.facialfeminizationsurgery.info).

\section{Cielesność osób transseksualnych}

W literaturze wskazuje się, że osoby transseksualne są więźniami własnych ciał - transseksualni mężczyźni cierpią w ciele kobiecym, transseksualne kobiety - w ciele męskim, co niejednokrotnie wiąże się z odrzuceniem swojego ciała, niechęcią do niego, awersją do zewnętrznych narządów płciowych (D ulk o 2008). Można wyróżnić trzy główne płaszczyzny, na których osoby transseksualne wykazują dezakceptację swojej cielesności:

1) elementy ciała jednoznacznie wskazujące na płeć jednostki - w przypadku transseksualnych mężczyzn są to piersi, genitalia, brak męskich trzeciorzędowych cech płciowych (np. męskiego owłosienia), zaś w przypadku transseksualnych kobiet są to genitalia, brak piersi oraz obecność męskich trzeciorzędowych cech płciowych;

2) elementy ciała w mniejszym stopniu nacechowane płciowo - m.in. wzrost, sylwetka, wielkość dłoni i stóp, kształt twarzy;

3) części ciała obarczone efektami ubocznymi zabiegów operacyjnych m.in. blizny na klatce piersiowej, podbrzuszu, ubytki tkanki mięśniowej i skóry (w przypadku phalloplastyki).

Przed rozpoczęciem procesu korekty płci osoby transseksualne bardzo często dokonują zabiegów maskujących części ciała wskazujących na ich płeć biologiczną. Osoby transseksualne typu K/M na drodze różnych zabiegów dążą do uzyskania płaskiej klatki piersiowej (bandażowanie, koszulki uciskowe), niekiedy różnymi przedmiotami imitują wypukłość w okolicach genitalnych. Natomiast osoby transseksualne typu $\mathrm{M} / \mathrm{K}$ dążą do zamaskowania genitaliów, niekiedy próbują zaaranżować wypukłości piersiowe.

\section{Opis badania}

Badanie zostało przeprowadzone $\mathrm{z}$ udziałem 16 osób transseksualnych: 12 osób typu K/M oraz 4 osób typu M/K. 
Osoby badane typu $\mathrm{K} / \mathrm{M}$ to:

- 4 osoby przed rozpoczęciem kuracji hormonalnej, po zakończonym procesie diagnostycznym (wiek 18-22 lata);

- 5 osób po mastektomii i histerektomii, w trakcie kuracji hormonalnej (wiek 23-28 lat);

- 3 osoby po zakończonym procesie korekty płci (wiek 30-36 lat).

Osoby badane typu M/K to:

- 4 osoby w trakcie kuracji hormonalnej, przed SRS (wiek 25-31 lat).

Zastosowano następujące narzędzia badawcze:

- Skala Oceny Ciała;

- autorska ankieta dotycząca stanu zdrowia.

Badanie było prowadzone w okresie styczeń - maj 2015.

Zadaniem osób badanych było określenie stosunku (pozytywny, neutralny, negatywny) do określonych przez badającego części swojego ciała z rozróżnieniem na elementy $\mathrm{w}$ znaczącym stopniu nacechowane płciowo (m.in. genitalia, piersi) oraz elementy w mniejszym stopniu nacechowane płciowo (m.in. stopy, przedramiona etc.). W kolejnej części respondenci mieli za zadanie określić swój stan zdrowia oraz wskazać negatywne skutki medycznej korekty płci.

$\mathrm{Z}$ powodu małej liczebności grupy respondentów dokonano jedynie jakościowej analizy wyników. Są one etapem początkowym szerzej zakrojonych badań nad transseksualnością. Oceny formułowane przez respondentów ujęto w formę tabel (1-4).

Tabela 1. Stosunek do własnego ciała osób transseksualnych typu K/M przed rozpoczęciem medycznej korekty płci

\begin{tabular}{|l|l|}
\hline \multicolumn{1}{|c|}{ Ocena } & \multicolumn{1}{c|}{ Część ciała } \\
\hline Pozytywna & twarz \\
\hline Neutralna & jabłko Adama, głos \\
\hline Negatywna & $\begin{array}{l}\text { pochwa, łechtaczka, piersi, wzrost, figura, biodra, } \\
\text { dłonie, owłosienie, stopy, wygląd zewnętrzny }\end{array}$ \\
\hline
\end{tabular}

Źr ódło: badania własne.

Wśród ocenianych pozytywnie części ciała pojawiła się jedynie twarz. Do negatywnych charakterystyk zaliczono elementy silnie nacechowane płciowo (genitalia, pochwa, piersi, owłosienie), a także wzrost, figurę, biodra, dłonie, stopy oraz ogólny wygląd zewnętrzny. 
Tabela 2. Stosunek do własnego ciała osób transseksualnych typu K/M w trakcie medycznej korekty płci

\begin{tabular}{|l|l|}
\hline \multicolumn{1}{|c|}{ Ocena } & \multicolumn{1}{c|}{ Część ciała } \\
\hline Pozytywna & twarz, wygląd zewnętrzny, piersi, głos, owłosienie \\
\hline Neutralna & jabłko Adama, figura, stopy, dłonie \\
\hline Negatywna & pochwa, łechtaczka, wzrost, biodra \\
\hline
\end{tabular}

Źr ódło: badania własne.

Osoby w trakcie androgenowej kuracji hormonalnej oraz po przebytej mastektomii i histerektomii pozytywnie oceniły swoją twarz, piersi, owłosienie ciała, głos oraz ogólny wygląd zewnętrzny. Wśród elementów ciała ocenianych negatywnie pozostały genitalia, biodra oraz wzrost. Figura, stopy oraz dłonie straciły negatywne nasycenie na rzecz stosunku neutralnego.

Tabela 3. Stosunek do własnego ciała osób transseksualnych typu K/M po medycznej korekcie płci

\begin{tabular}{|l|l|}
\hline \multicolumn{1}{|c|}{ Ocena } & \multicolumn{1}{c|}{ Część ciała } \\
\hline Pozytywna & $\begin{array}{l}\text { twarz, wygląd zewnętrzny, piersi, głos, owłosienie, } \\
\text { dłonie, pochwa, łechtaczka }\end{array}$ \\
\hline Neutralna & jabłko Adama, figura, stopy, biodra wzrost \\
\hline Negatywna & brak \\
\hline
\end{tabular}

Źr ódło: badania własne.

Po ukończonym procesie korekty płci osoby transseksualne oceniają części swojego ciała pozytywnie oraz neutralnie. Żadne elementy nie są oceniane negatywnie.

Tabela 4. Stosunek do własnego ciała osób transseksualnych typu M/K przed SRS (w trakcie kuracji hormonalnej)

\begin{tabular}{|l|l|}
\hline \multicolumn{1}{|c|}{ Ocena } & \multicolumn{1}{c|}{ Część ciała } \\
\hline Pozytywna & brak \\
\hline Neutralna & biodra, jabłko Adama, stopy, głos \\
\hline Negatywna & $\begin{array}{l}\text { twarz, piersi, dłonie, wzrost, moszna, figura, penis, } \\
\text { owłosienie, wygląd zewnętrzny }\end{array}$ \\
\hline
\end{tabular}

Źr ó dło: badania własne. 
Osoby transseksualne typu $\mathrm{M} / \mathrm{K}$ w trakcie estrogenowej kuracji hormonalnej (przed SRS) większość części ciała oceniają negatywnie. Do oceny neutralnej zaliczono jedynie jabłko Adama, biodra, stopy i głos. Nie odnotowano ocen pozytywnych.

\section{Doświadczanie efektów ubocznych kuracji hormonalnych i zabiegów operacyjnych}

Określając swój stan zdrowia oraz wskazując negatywne skutki medycznej korekty płci, osoby transseksualne $\mathrm{K} / \mathrm{M}$ wymieniły:

- w związku z kuracją hormonalną: zaburzenia krzepliwości krwi, trądzik, łysienie, obrzmienie łydek, zaburzenia kardiologiczne, nadmierne pocenie się, nadmierne przybieranie na wadze, bóle głowy, osłabienie, wzmożone napięcie;

- po histerektomii: krwotoki, nietrzymanie moczu, bolesne podbrzusze, infekcje układu moczowego;

- w wyniku phalloplastyki: zaburzenia czucia, nadwrażliwość w miejscach pobrania tkanek, infekcje układu moczowego.

Określając swój stan zdrowia oraz wskazując negatywne skutki medycznej korekty płci, osoby transseksualne $\mathrm{M} / \mathrm{K}$ wymieniły:

- bóle głowy, mdłości, bóle piersi, zaburzenia apetytu, obniżenie/brak popędu seksualnego.

\section{Wnioski}

Osoby transseksualne niewątpliwie znajdują się w ekstremalnie trudnej sytuacji życiowej. Są więźniami własnych ciał, na co dzień doświadczając nietypowego rozdźwięku między psyche a somą, który powoduje silne poczucie cierpienia. Proces korekty płci - jedyna skuteczna metoda leczniczo-terapeutyczna - jest długotrwały, kosztowny oraz bardzo obciążający dla poddającej się mu osoby. Niewątpliwie jednak w pozytywny sposób wpływa na dobrostan ogólny osoby transseksualnej. Zaprezentowane $\mathrm{w}$ niniejszym artykule badania zostały przeprowadzone z małą grupą respondentów, dlatego też wyniki poddano jedynie analizie jakościowej. Mimo to wyłaniają się pewne prawidłowości. Osoby transseksualne typu K/M po ukończonym procesie diagnostycznym, ale przed medyczną korektą płci, oceniają swoje ciało najniżej wśród przebadanych transseksualnych mężczyzn. Jedynym pozytywnie postrzeganym elementem jest twarz, natomiast genitalia, piersi, owłosienie, a także wzrost, figura, biodra, dłonie, stopy i ogólny wygląd zewnętrzny oceniano w sposób jednoznacznie negatywny. Ocena ciała zmienia się wraz z postępowaniem procesu korekty płci. Osoby, które poddają się androgenowej kuracji hormonalnej oraz przebyły mastektomię i histerektomię, 
lepiej oceniają elementy swojego ciała. Pozytywnie są oceniane: klatka piersiowa po usunięciu chirurgicznym piersi, owłosienie ciała nabyte na skutek androgenowej kuracji hormonalnej oraz barwa głosu, obniżona wskutek działania testosteronu. Negatywne nastawienie do figury, stóp i dłoni ustępuje miejsca neutralnemu ich traktowaniu. Co ciekawe, osoby typu K/M po przebyciu wszystkich zabiegów operacyjnych żadnego elementu swojego ciała nie oceniły w sposób negatywny. Genitalia, piersi, owłosienie, dłonie, głos i ogólny wygląd zewnętrzny spotkały się z pozytywną oceną. Pozostałe charakterystyki zostały uznane za neutralne. Można to thumaczyć faktem, że wraz z biegiem czasu następuje coraz większa pewność, utwierdzanie się roli męskiej oraz wzrost samooceny. Dochodzi do przewartościowania wielu spraw, w tym własnej cielesności. Po kilkuletnim funkcjonowaniu w roli męskiej figura, wielkość stóp czy dłoni nie jest konieczna do potwierdzania swojej płciowości.

Osoby transseksualne typu $\mathrm{M} / \mathrm{K}$ w trakcie estrogenowej kuracji hormonalnej, ale przed SRS, niżej niż transseksualni mężczyźni oceniają swoje ciało. Kilka elementów (biodra, jabłko Adama, stopy, głos) oceniono neutralnie, pozostałe zaś - jednoznacznie negatywnie. Biorąc pod uwagę fizjologię człowieka, trudniej jest sfeminizować ciało męskie niż zmaskulinizować ciało żeńskie. W badaniu nie brały udziału osoby, które przeszły SRS, w związku z czym nie można było zaobserwować różnic w postrzeganiu swojego ciała u osób po medycznej korekcie płci.

Kuracje hormonalne oraz zabiegi operacyjne nie są wolne od skutków ubocznych. Respondenci wskazali różne dysfunkcje w zakresie zdrowia somatycznego. Nie były one jednak dla nich na tyle obciążające, by pominąć którykolwiek etap procesu korekty płci. Mimo dużego postępu medycznego na przestrzeni ostatnich kilkudziesięciu lat, oferta skierowana do osób transseksualnych nadal wymaga doskonalenia.

W badaniu widoczna jest dysproporcja między liczebnością osób transseksualnych typu $\mathrm{K} / \mathrm{M}$ a $\mathrm{M} / \mathrm{K}$. Transseksualizm jest zjawiskiem rzadko występującym w populacji - szacuje się, że dotyka $0,001-0,002 \%$ osób, przy czym wśród genetycznych mężczyzn występuje 3-krotnie częściej niż u genetycznych kobiet (Urban 2009). Jednak w Polsce i innych krajach Europy Wschodniej proporcje są odwrotne - częściej występuje transseksualizm K/M, który zyskuje nawet 5,5-krotną przewagę (Urban 2009; Cohen-Kettenis, Gooren 1999). Przyczyny tego zjawiska nie są znane.

W artykule zostały wskazane dalsze plany eksploracji tematyki funkcjonowania osób transseksualnych. Autor zamierza poszerzyć badania - z udziałem większej liczby respondentów - o zagadnienia dotyczące struktury poznawczej osób transseksualnych, ich osobowości, funkcjonowania społecznego, rodzinnego, relacji partnerskich oraz funkcjonowania seksualnego. 


\section{Bibliografia}

Antos zews ki B., Żą dzińska E. (2008), The Metric Features of Teeth in Female-to-Male Transsexuals, „Archives of Sexual Behavior”, Vol. 38, s. 351-358.

Chiland C., Clouet A.-M., Golse B., Guinot M., Wolf J. P. (2013), A new type of family: Transman as fathers thanks to donor sperm insemination. A 12-year follow-up exploratory study of their children, „Neuropsychiatrie de l'enfance et de l'adolescence”, Vol. 61, s. $365-370$.

C o h e n-K e t t e n is P. T., G o o r e n L. J. G. (1999), Transsexualism: a review of etiology, diagnosis and treatment, ,Journal of Psychosomatic Research”, Vol. 46, No. 4, s. 315-333.

C z a r n e c k a A. (2003), Czy mózg ma płeć? Różnice w budowie ludzkiego mózgu, „Kosmos. Problemy Nauk Biologicznych", T. 52, nr 1, s. 21-27.

D u 1 k o S. (2008), Modele partnerstwa i relacji matżeńskich transseksualistów typu kobieta-mężczyzna i mężczyzna-kobieta, „Przegląd Seksuologiczny”, nr 16, s. 5-11.

D zi e m i a A., Ł u cka I. (2008), Transseksualizm czy zinternalizowana homofobia - studium przypadku, „Psychiatria Polska”, T. 42, nr 1, s. 105-114.

Green R., Young R. (2001), Hand Preference, Sexual Preference and Transsexualism, „Archives of Sexual Behavior", Vol. 30, No. 6, s. 565-574.

I m i e l ińs k i K., D u l k o S. (1988), Przekleństwo Androgyne. Transseksualizm: mity i rzeczywistość, Wydawnictwo Naukowe PWN, Warszawa.

I m i elińs k i K., D ulko S. (2001), Przekleństwo Androgyne, Wydawnictwo ARC-EN-CIEL, Kraków.

P u ż y ń s k i S., W c i ó r k a J. (2000), Klasyfikacja zaburzeń psychicznych i zaburzeń zachowania ICD-10, Uniwersyteckie Wydawnictwo Medyczne „Vesalius”, Kraków.

K u la K., S ło w i k o w s k a - H i l c z e r J. (2003), Kliniczne znaczenie badań nad różnicowaniem i dymorfizmem ptciowym mózgu, „Psychiatria w Praktyce Ogólnolekarskiej” nr 3(1), s. 7-16.

K u la K., S ło w i kow s k a - H ilc ze r J. (2012), Zaburzenia determinacji i różnicowania ptci, [w:] A. Szczeklik (red.), Choroby wewnętrzne. Stan wiedzy na rok 2012, Wydawnictwo Medycyna Praktyczna, Kraków.

Malinowski A., Maci ołe k B lewniewska G. (2007), Dlaczego histerektomia pochwo$w a$ ?, „Ginekologia Polska”, T. 78, nr 6, s. 434-442.

M a n d a l E. (2003), Kobiecość i męskość, Wydawnictwo Akademickie Żak, Warszawa.

M a t u s i k - K i t a M., Z d r oj e w i c z Z. (2009), Orgazm po zabiegach ginekologiczno-urologicznych, „Przegląd Seksuologiczny”, nr 19, s. 5-9.

N ow o s i e ls k i K. (2010), Identyfikacja i rola ptciowa, [w:] Z. L e w - S ta r o w i c z, V. S k r zyp u 1 e c (red.), Podstawy seksuologii, PZWL, Warszawa.

P a n k ow ska D. (2005), Wychowanie a role płciowe, Gdańskie Wydawnictwo Psychologiczne, Gdańsk.

R aw a-Kochanows k A A. (2011), Poczucie tożsamości płciowej w teorii i badaniach, Difin, Warszawa.

S el i g m a n M. E. P., Walke r E. F., R o s e n h a n D. L. (2003), Psychopatologia, Zysk i S-ka, Poznań.

Strze le c k a A., K o z e r a P. (2007), Płeć pomylono, „Charaktery”, nr 3, s. 66 - 69.

U r b a n M. (2009), Transseksualizm czy urojenia zmiany płci? Uniknać błędnej diagnozy, „Psychiatria Polska”, T. 43, nr 6, s. 719-728. 


\section{Netografia}

http://transhealth.vch.ca

http://www.staff.amu.edu.pl

$\mathrm{http}: / / \mathrm{www}$.gires.org.uk

http://www.healthnet.com

http://www.facialfeminizationsurgery.info

www.granicenauki.pl

\section{Jonasz Wethacz}

\section{ASSESSMENT OF ONE'S OWN BODY AND THE HEALTH STATUS OF TRANSGENDER PEOPLE}

Summary. Transsexualism is defined as a disturbance of gender identity, which is based on the discrepancy between mental sense of belonging to a particular gender and biological physique, sex by register, social, and legal. Since there is no method that would allow the matching of gender identity to the human body, the impact of healing-therapeutic focus is on the opposite treatment: adjusts physicality to that demonstrated gender identity. This indicates that transgender people are prisoners of their own bodies-transgender men suffer in the body of the female, transsexual women - in the male body, which often involves the rejection of his body, aversion to him, averse to external genitals. The process of gender reassignment takes place on many levels, including a multi-faceted diagnosis, a legal change of personal data, hormone treatment and surgery. Transgender people are exposed to many side effects of hormone treatment and post-operative complications. Also it indicates that medical gender reassignment process reduces the survival of a dozen to several dozen years. In this paper will be presented subjects of corporeality and the health of transgender people. The author will analyze the answers for the assessment of one's own body and health status granted by 16 transgender people who participated in the study. They are the beginning of more extensive research on various aspects of gender identity disorders.

Keywords: gender identity, transsexual, gender correction, physicality, health. 